\title{
Flower Development and Its Implication for Seed Production on Amorphophallus muelleri Blume (Araceae)
}

\author{
Edi Santosa ${ }^{1,2^{*}}$, Adolf Pieter Lontoh ${ }^{1}$, Ani Kurniawati ${ }^{1}$, Maryati Sari ${ }^{1}$ and Nobuo Sugiyama ${ }^{3}$ \\ Diterima 18 Maret 2016/Disetujui 06 Juli 2016
}

\begin{abstract}
There are many studies on agronomic and economic advantages of iles-iles (Amorphophallus muelleri Blume), leading to high demand on seed to support the rapid production expansion in many Asian countries. By contrast, there are few studies on flowering phenology and flower morphology although they affect the seed production. Therefore, we evaluated flowering phenology and flower morphology of 80 plants of A. muelleri grown in a field under $65 \%$ artificial shading net at Leuwikopo Experimental Farm IPB Darmaga, Bogor, Indonesia from May 2015 to July 2016 in order to improve seed production. A. muelleri produced solitary spadix, with female flowers at the lower part and male flowers at the upper part. Spadix grew slowly for 56-71 days after bud break, and then grew rapidly thereafter for 30-35 days until anthesis. Seed was harvested 9.6 to 10.2 months after anthesis. We devided the development of spadix into seven phases, bud break as stage I and berry maturity as stage VII. Stage VI to VII determined seed production. Seed production was also affected by root formation and spadix size. There were strong positive correlations between length of the female zones with berry production. Some morphological characteristics of spadix were dependent on corm size, thus, it was likely that agronomic improvement to enhance female flower and corm sizes was important in seed production.
\end{abstract}

Keywords: developmental stage, female flower, iles-iles, male flower, seed production

\section{ABSTRAK}

Telah banyak kajian keunggulan agronomi dan ekonomi iles-iles (Amorphophallus muelleri Blume), sehingga mendorong peningkatan permintaan benih untuk mendukung perluasan areal produksi di banyak negara Asia. Namun demikian, kajian fenologi dan morfologi bunga khususnya terkait produksi benih masih terbatas. Oleh karena itu, kami mengkaji perkembangan dan morfologi 80 bunga iles-iles yang ditanam di bawah paranet 65\% di Kebun Percobaan Leuwikopo IPB, Bogor, Indonesia dari Mei 2015 sampai Juli 2016 dalam rangka perbaikan produksi benih. Iles-iles menghasilkan sebuah tongkol bunga dengan bunga betina pada bagian bawah dan bunga jantan pada bagian atas. Tongkol bunga tumbuh lambat 58-71 hari setelah pecah tunas, diikuti tumbuh cepat 3035 hari hingga antesis, dan biji dipanen 9.6 sampai 10.2 bulan setelahnya. Perkembangan bunga dari pecah tunas hingga buah matang dapat dibagi menjadi tujuh tahap. Tahap VI ke tahap VII menentukan keberhasilan produksi biji iles-iles. Selain itu, keberhasilan produksi biji juga dipengaruhi oleh keberadaan akar dan ukuran tongkol khususnya panjang bagian bunga betina. Beberapa karakter morfologi bunga iles-iles dipengaruhi oleh ukuran umbi saat tanam. Oleh karena itu, perlu perbaikan agronomis untuk meningkatkan ukuran umbi dan ukuran bunga betina guna mendukung produksi benih.

Kata kunci: bunga betina, bunga jantan, iles-iles, produksi benih, tahap pertumbuhan

\section{INTRODUCTION}

Amorphophallus muelleri Blume (called iles-iles or porang in Indonesian), an Araceae, is believed to be native to Java (Ohtsuki, 1968), and it is usually grown in intercropping systems (Santosa et al., 2003). Three-year-old corms are harvested to produce glucomannan 
flour, which is hardly digestible carbohydrate and used as food and raw materials for pharmaceutical cosmetic manufacturing (Jansen et al., 1996; Alonso-Sande et al., 2009).

Growing areas of A. muelleri are increasing in many Asian countries; reached about 10000 ha in Indonesia (Santosa, 2014) and 10 million ha in China in early 2000 (Zhao et al., 2013). Ekawati et al. (2010) stated that shading treatment elucidated growth and productivity increasement of several indigenous vegetable. Santosa et al. (2003) and Sugiyama and Santosa (2008) reported cultural practices of $A$. muelleri in intercropping systems in East Java, and that the intercropping systems increase income level and enhance social stability of farmers. Zhang et al. (2010) revealed that productivity is dependent on growth duration and the degree of corm dormancy. Studies have been carried out on the effects of seed corm age and corm weight on corm yield (Sumarwoto 2005; Zhao et al., 2010). However, it is little known on seed production.

A. muelleri corms usually flower for the first time at the fourth year after planting of seeds or bulbils (Jansen et al., 1996; Sumarwoto, 2005). However, many farmers remove flower buds in order to maintain high glucomannan production, thus flowering of $A$. muelleri plants are rare in fields (Santosa et al., 2003). Flowers produce triploid $(2 \mathrm{n}=3 \mathrm{x}=39)$ apomictic seeds (Jansen et al., 1996); thus progenies are genetically identical to the maternal plant (Hand and Koltunow, 2014), preventing cross breeding. Therefore, there were few studies on flower morphology and flowering phenology. Sugiyama and Santosa (2008) reported that corm size determined the size of reproductive organs including peduncles, spathes and spadices, but not seed production in A. muelleri. In present study, we studied inflorescence morphology and phenology of $A$. muelleri in relation to seed production.

\section{MATERIALS AND METHODS}

Field research was conducted at Leuwikopo Experimental Farm, Bogor Agricultural University, Bogor, West Java,
Indonesia from May 2015 to July 2016. Daily temperatures during the experiment ranged from 25 to $35{ }^{\circ} \mathrm{C}\left(28{ }^{0} \mathrm{C}\right.$ on average) and relative air humidity ranged from 78 to $86 \%$ ( $80 \%$ on average). Soil $\mathrm{pH}$ was 5.64 , with a low amount of total $\mathrm{N}(0.28 \%$ by Kjeldahl method), low amount of Bray I phosphorus (34.02 $\mathrm{mg} \mathrm{kg}^{-1}$ ) and high amount of potassium (174.78 $\mathrm{mg} \mathrm{kg}^{-1}$ ).

Three-year-old corms were harvested on May 10, 2015 and kept at room temperature until breaking of dormancy in August 2015. At the time of bud break (about 2-3 cm), corms with flower buds were planted, whereas those with 'unidentified' buds were dissected to identify reproductive buds. Eighty-seven corms were planted in an equidistance planting pattern $(60 \times 60 \times 60 \mathrm{~cm})$, at $3-4 \mathrm{~cm}$ depth on September 3, 2015. Prior to planting, individual corm weight and diameter were measured. Five two-year-old corms after flowering were planted as control.

Tillage was performed in Latosol Darmaga soil with lime at a rate of 1 ton per ha. In every planting hole, $0.5 \mathrm{~kg}$ goat manure $(1.13 \%$ total $\mathrm{N}, 0.07 \%$ available $\mathrm{P}$ and $0.28 \%$ available K) was applied one month prior to planting. Planting area was shaded by paranet that blocked $65 \%$ of sunlight. Watering was carried out using sprinkler when rainfall was less than $3 \mathrm{~mm}$ for two consecutive days. No supplemental NPK fertilizers were applied.

Most corms $(80$ corms $)$ produced reproductive buds and seven other produced vegetative buds, therefore evaluation was conducted for the 80 spadices. Spadix growth was monitored every two days. Size of sheaths (bracts or cataphylls), peduncles, spathes, female flowers, male flowers and appendices was measured (Figure 1). Flower odor was observed by sniffing. Three to four flowering corms where selected and destructively observed when they reached a certain stage as characterized in Figure 2. Anthesis was determined as a time when spathe reached full expansion or inflorescence emitted odor.

One-way of analysis of variance (ANOVA) was performed and mean separation was carried out by Tukey's range test. A chi-square $\left(\chi^{2}\right)$ test was performed to test the fit between a theoretical and an observed frequency distribution data. 


\section{RESULTS AND DISCUSSION}

\section{Flower and Vegetative Buds}

Before flower bud emergence, dormant period lasted for 2.5 to 3 months after harvest on May 10, 2015 (Figure 2). At breaking of dormancy, all corms had a single swollen and bright-pink bud at the center of corm cavity. Bud diameter and height were $0.8-1.2 \mathrm{~cm}$ and $0.5-0.7 \mathrm{~cm}$, respectively. We found that large buds derived from large corms $(>14 \mathrm{~cm}$ in diameter) usually emerged earlier than small buds derived from smaller corms $(<12 \mathrm{~cm}$ in diameter), irrespective of vegetative and flower buds (Figure 2).

Flower buds were distinguishable from vegetative buds when buds started to enlarge or bud length reached ca 2-3 cm, i.e., 56 to 71 days (average 68 days) after break dormancy. Flower buds were conical-cylindrical shape with dull apex (obtuse), while vegetative buds were almost perfect conical shape with acute apex (Figure 3A). Furthermore, vegetative buds were easily squashable between thumb and first fingers, whereas flower buds were hard textured (Figure 3B). Discrimination between vegetative and flower buds based on its shape and texture corresponded to that based on the dissection of buds was at a rate of $92 \%$ in the experiments using additional corms.

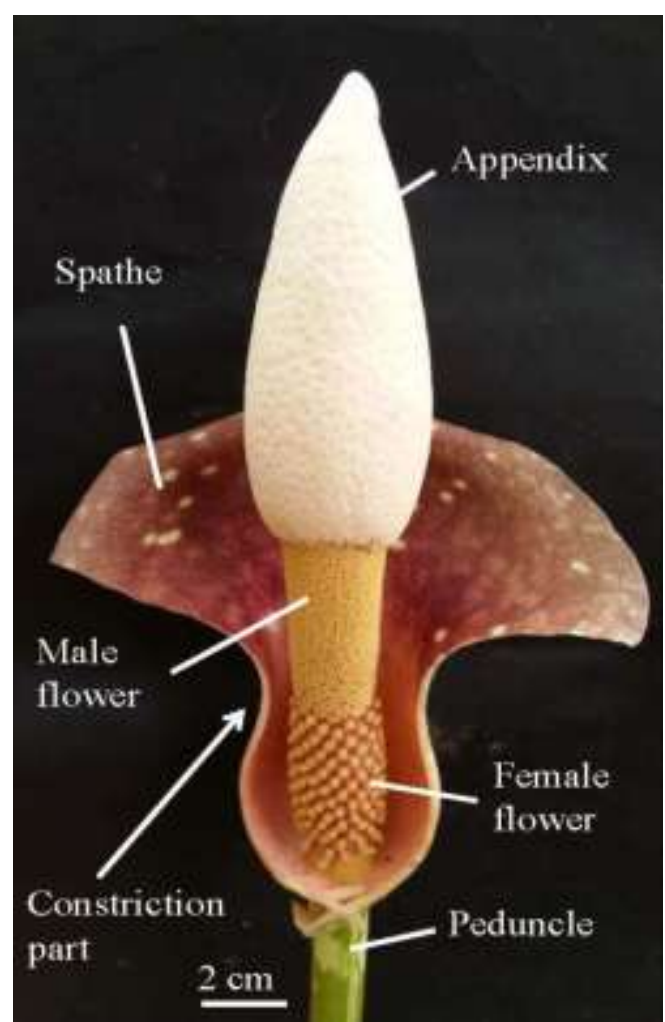

Figure 1. Spadix of A. muelleri with female flower zone at the lower, male flower zone at the middle and appendix as sterile zone at the upper part.

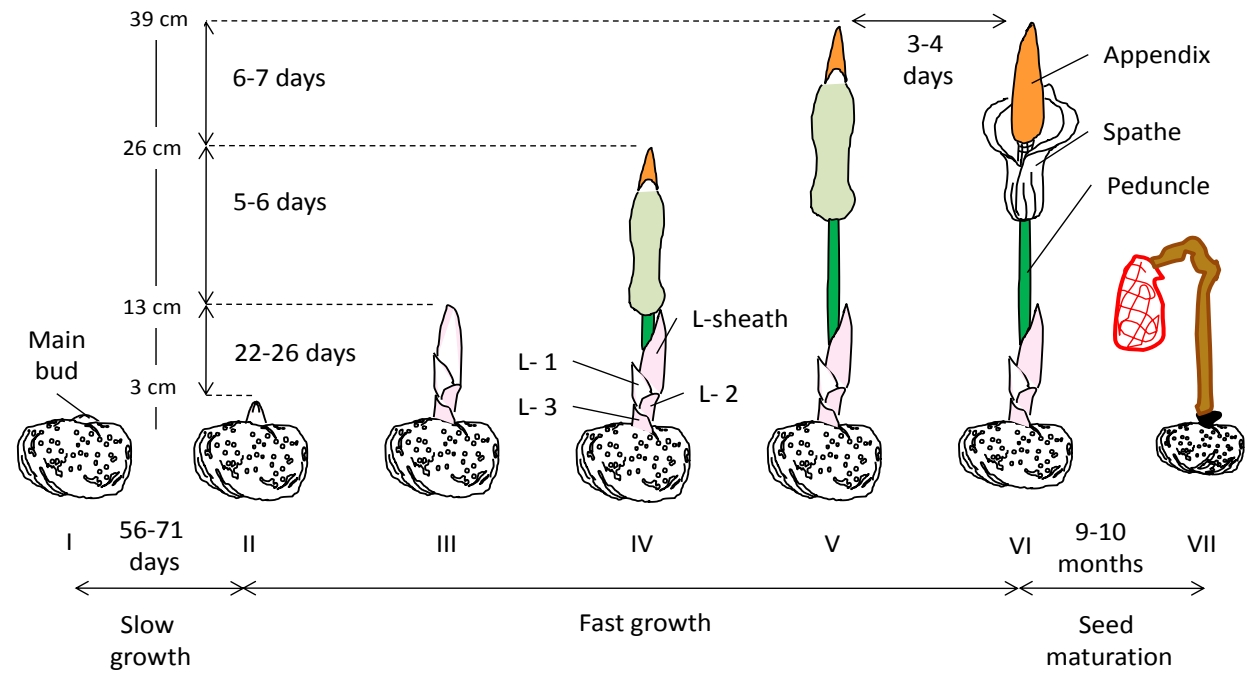

Figure 2. Spadix development of A. muelleri from flower bud to seed maturation. L-last sheath, L-1 one sheath before L-sheath emergence, etc. Phase I, break dormancy 2.5-3 months after harvest. Phase II, emergence of flower bud (spadix) 56-71 days after break dormancy. Phase III, elongation of spadix 22-26 days after emergence. Phase IV, spadix out of sheaths 5-6 after elongation. Phase V, spadix reaches maximum size 6-7 days after out of sheaths. Phase VI, anthesis 3-4 days after maximum. Phase VII, berry mature 9-10 months after anthesis. Drawing without scale. 


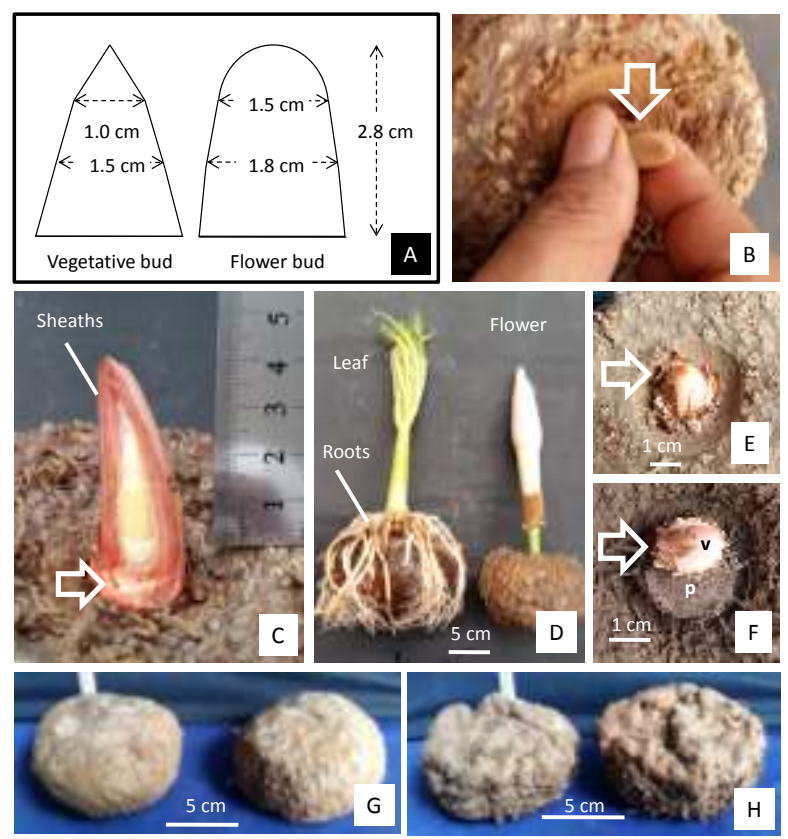

Figure 3. Flower bud and corm morphology of A. muelleri. A. Shape of vegetative and flower buds. B. Identification of flower bud. C. Flower bud with protective 8 sheaths. D. Shoot with roots (left) and inflorescence without roots (right). E. Vegetative bud at the middle of cavity from vegetative corm. F. Vegetative bud from flowering corm (v) at edge of remnant peduncle base (p). G. Smooth corms before flowering. H. Corrugated corms after produced seeds. Arrows indicate the position of bud.

Flower buds were covered by sheaths (Figure 3C), which were considered to protect the flower bud from physical damage such as soil impedance or insects. Prior to flower emergence, 5-8 sheaths developed with different length; the first to the fourth sheaths were nearly similar in length (ca. 0.5 to 0.8 $\mathrm{cm}$ ), whereas the fifth and upper sheaths extended longer (1.1 and $15.8 \mathrm{~cm}$ for the fifth and the last sheaths, respectively). All sheaths were pink in color, irrespective of the sequence of emergence.

It is interesting to note that root growth during flower development was depressed or completely suppressed, unlike roots of vegetative corms (Figure 3D). In both vegetative and flowering corms, roots emerged from the swollen base of petiole and peduncle, respectively. Average number of roots, at 30 days after bud break, ranged from 2 to 14 in flowering corms, and from 29 to 75 in vegetative corms. According to Fred Rumawas (personal communication, February 24, 2016), flowering corm without roots remained dormant when the inflorescence was removed, but when the inflorescence of flowering corm with roots was removed the corm would produce leaf and develop vegetatively.

A corm produced a solitary single inflorescence. No leaf was formed during flowering, although there were an inactive main leaf bud (ca $0.5-1.0 \mathrm{~cm}$ in length) beside the base of peduncle (see arrow of Figure 3C) and several small auxiliary leaf buds around the main leaf bud (Figure 3F). It is probably that apical dominance is strong in growing corm, leading to the suppression of leaf bud elongation in A. muelleri. The difference in the position of main vegetative buds on corms after corm produced leaf (Figure 3E) and inflorescence (Figure 3F) was noted.

After berry mature, corms became flattened, and their skin were wrinkled (Figure $3 \mathrm{H}$ ), unlike smooth skin before flowering corms (Figure 3G). Sumarwoto (2005) stated that glucomannan content of corms decreased by about $4-27 \%$ and $26-42 \%$, respectively, after the formation of inflorescence and seeds, thus the corms after flowering were sold at a discount of $50-70 \%$ (Sugiyama and Santosa, 2008). 


\section{Flower Morphology}

Inflorescence had green long peduncle with tinny diamond spots, stripes and irregular-shaped spots. Creamy white spots or green spots encircled with white lines were common. Peduncle length varied from 14.8 to $38.9 \mathrm{~cm}(16.0 \mathrm{~cm}$ on average $)$, and its diameter tapered, i.e., $1.6 \pm 0.4 \mathrm{~cm}$ at the base, $1.5 \pm 0.3$ $\mathrm{cm}$ in the middle and $1.4 \pm 0.4 \mathrm{~cm}$ at the upper portion (Table 1). Inflorescence height including appendix ranged from 27.5 to 45.0 $\mathrm{cm}$, with an average of $39.0 \mathrm{~cm}$, that is likely relate to corm size.

Inflorescence, called spadix, consisted of single spathe, female flower zone, male flower zone and appendix (Figure 1). Abaxial side of spathe was pinkish/reddish light brown, while adaxial side was purplish-pink to dark purplish-red at anthesis. There was a marked constriction zone between female and male flower zones at the middle of spathe (Figure 1). Length of spathe ranged from 13 to $18 \mathrm{~cm}$, and the maximum width ranged from 8 to 15 $\mathrm{cm}$. At full expansion (anthesis), the edge of spathe commonly twisted outward (Figure 4A).

Appendix was commonly conical in shape (Figure 1 and Figure 4A). The appendix length ranged from 9.0 to $15 \mathrm{~cm}(12.0 \mathrm{~cm}$ on average) (Table 1), and its diameter ranged from 3.0 to $6.8 \mathrm{~cm}$. Creamy white or purplish white appendices were most common at anthesis. Vertical cross section showed that the entire appendix was spongy tissue (Figure 4B), suggesting that appendix expanded markedly prior to anthesis and emitted odor. The appendix facilitates odor emission (Kite and Hetterschieid, 1997).

Table 1. Inflorescence size in A. muelleri measured at anthesis

\begin{tabular}{lc}
\hline Characters & Size \pm SD $(\mathrm{cm})$ \\
\hline Peduncle length & $16.0 \pm 4.9$ \\
Peduncle diameter & \\
$\quad$ Lower & $1.6 \pm 0.4$ \\
$\quad$ Middle & $1.5 \pm 0.3$ \\
$\quad$ Upper & $1.4 \pm 0.4$ \\
Spadix length & $23.0 \pm 4.4$ \\
Spathe length & $16.3 \pm 2.7$ \\
Female zone length & $5.1 \pm 1.1$ \\
Male zone length & $5.9 \pm 0.8$ \\
Appendix length & $12.0 \pm 2.9$ \\
\hline SD means standard deviation &
\end{tabular}

Female and male flowers were located at separate positions, but sometimes transition zone (bisexual zone) was found. Clear transition zones were commonly formed between female and male zones, and between male zone and appendix. However, some inflorescences showed additional form at the transition zones between male zone and appendix (Figure 4C).

Length of male zone varied from 3.2 to $7.8 \mathrm{~cm}$, with an average of $5.9 \mathrm{~cm}$ (Table 1), and diameter of $2.0-2.4 \mathrm{~cm}$. Anthers of male flowers were creamy or dark yellow. Number of anther in a spadix ranged from 475 to 2810 (1495 on average). An anther had two pollen sacs. Anthers distributed densely at middle and upper portions, and sparsely at lower portion of male zone. A male flower was considered to have three to five anthers with four anthers as the most common (see Figure 4D). Therefore, in a spadix, number of male flower was calculated range from 119 to 703 (392 on average).

Length of female zone ranged from 4.5 to 6.7 $\mathrm{cm}, 5.1 \mathrm{~cm}$ on average (Table 1). Female flowers as represented by color of ovaries were dark red, pink or light pink in color at anthesis (Figure 4E), inline with report of Sugiyama and Santosa (2008). Below the female zone, there was a $0.5-1.1 \mathrm{~cm}$ long sterile stipule (see lower arrow Figure 4F). Number of female flowers ranged from 40 to 825 (174 on average). Number of stigmatic lobes was commonly two. One, three, four, five and or more lobes sometimes existed in an inflorescence (Figure 4E, indicated by arrow). At inflorescence with predominant two lobes, ovaries with three lobes was commonly 3 to $4 \%$; the highest percentage was upto $15 \%$ in a spadix. Since the number of lobes corresponded to the number of seeds, it is interesting to investigate the variation in lobe number in A. muelleri.

\section{Stage of Flower Development}

Spathe was distinguishable from sheath by observing vertical sectional view when bud reached about 2 to $3 \mathrm{~cm}$ in height. After breaking of dormancy, flower bud grew slowly for about two months (56 to 71 days), and then entered a rapid growth phase which lasted for one month (30 to 35 days). Rapid growth phase was characterized by sheath elongation, followed by peduncle and spadix elongation, and anthesis (Figure 2). 


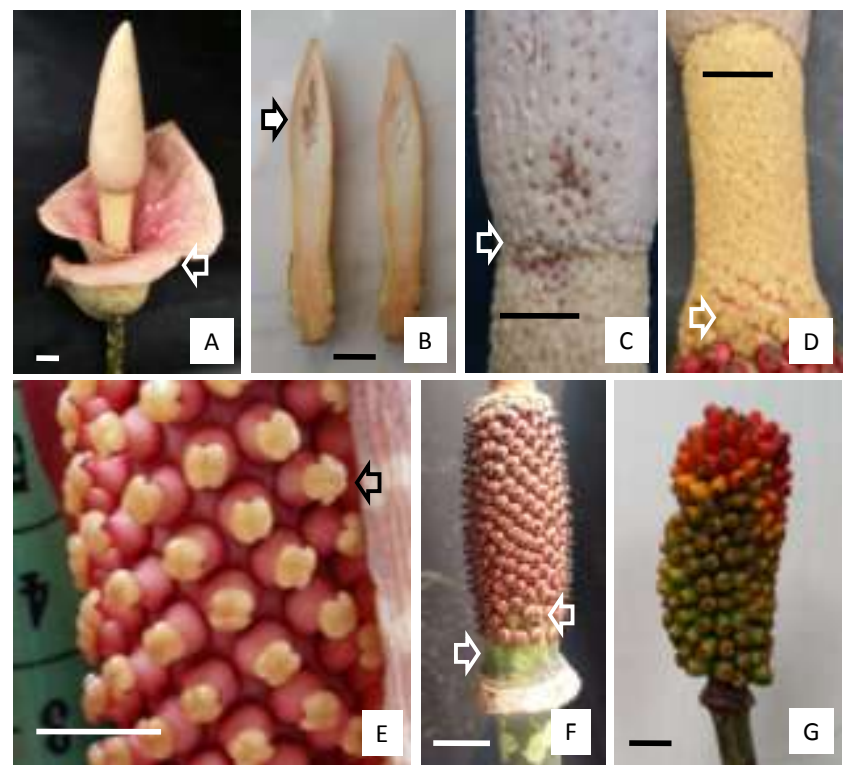

Figure 4. Flower organ of A. muelleri. A. Spathe twist outward (arrow). B. Vertical section of spadix shows spongy form (arrow). C. Transition zone between appendix (upper) and male flowers (lower). D. Male zone (a male flower indicated by arrow). E. A stigma with three lobes indicated by arrow, different from the common two lobes. F. Immature berries with large seed (upper arrow) and stipule (lower arrow). G. Mature berries. Bar $1 \mathrm{~cm}$.

Morphologically, the flower development could be classified into seven phases (Figure 2). Buds released dormancy at stage I, then elongated. Bud reached $3 \mathrm{~cm}$ in size at stage II, and all sheaths reached maximum size at stage III. Spadices inside sheaths continued to develop and pushed its way out of sheaths at stage IV, and reached a maximum size at Stage V. Spathes began to open and anthesis at stage VI, and followed by ovaries developed to mature berries at stage VII. Stages I-II, II-III, III-IV, VI-V and V-VI lasted for 56 to 71 days, 22 to 26 days, 5 to 6 days, 6 to 7 days and 3 to 4 days, respectively.

From stage I to II, four sheaths were commonly formed. Another four sheaths, i.e., the $5^{\text {th }}, 6^{\text {th }}, 7^{\text {th }}$ and $8^{\text {th }}$ sheaths, were elongated from stage II to III. For the sake of simplicity, the $8^{\text {th }}$ sheath was called as the last (L) sheath. After the $5^{\text {th }}$ sheath (L-3) reached full size, the $6^{\text {th }}$ sheath (L-2) started to elongate, and just the same for the $7^{\text {th }}(\mathrm{L}-1)$ and the $8^{\text {th }}$ sheath (L) subsequently (Figure 2).

Some variations in colors of spathe and appendix became apparent at stage III. Stage IV was characterized by the same length of peduncle and L-sheath. From stage IV to V, peduncle and spadix elongated at a rate of ca 0.8 to $1.0 \mathrm{~cm} \mathrm{day}^{-1}$. Appendix had fully inflated at this stage. Stage $\mathrm{V}$ was characterized by the time at which spathe began to open, and spathe opening was completed within 4 to 5 days at stage VI (Figure 2). In some inflorescence, peduncle and spadix elongated slightly between stage $\mathrm{V}$ and VI.

Stage VI was characterized by the spathe of which margin wrinkled outward (Figure 4A) or appendix and male flower emitted odor. It appears that relative air humidity affected the duration of spathe opening. Stigma lobe remained receptive for two days in hot and dry condition, but for four days in humid conditions after rain indicating by its freshness. Stigma lobe had been sticky from one day before anthesis and remained to release oily substance up to 1.5 months thereafter.

Ovary color was creamy white at the beginning of stages II and greenish at the end of stage, and it turned to pinkish white or creamy white at stage III (Table 2). Male flowers usually shed sticky pollen continuously at 02:00 pm one day prior to and at anthesis, being adherent to each other and forming a short chain. Microscopic observation showed that most pollen grains released from anther were translucent, but some pollen grains were yellow or green. Sumarwoto (2005) reported that green and 
yellow pollen were fertile and sterile, respectively, but he did not mention anything about translucent pollen. It is necessary to check pollen viability in A. muelleri.

Spathe, male flowers and appendix withered within 2 to 4 days after anthesis (opening of spathe), and detached solely from peduncle after 2.5 to 3 months. During the development of berries (ovary), their colors gradually changed from dark red to brown/light yellow/pink, and then to light green/dark green, subsequently. Female zone elongated slightly by about 3 to $7 \mathrm{~cm}$ inline with berries enlargement. At maturity stage, they turned from dark green to bright yellow, then to orange and bright red color, with gradual changes in color downward from the upper of infructescence.

After berries had matured, peduncle withered at stage VII; it took 281 to 307 days (9.6 to 10.2 months) from anthesis (Figure 4G) or 368 to 405 days after planting (Table 2). In the present study, many berries of flowering corm without roots failed to set seed leading to produce less seed than those with roots. It is presumably that absent of root disturbs seed development during stage VI to VII in $A$. muelleri. Further study is needed to clarify why flowering corms produced a small number of roots.

\section{Morphometric Characters of Flowers}

There was a significant correlation between corm size and diameter of peduncle (Table 3). This finding was inline with the previous study of Santosa et al. (2003) who reported that petiole diameter was a good estimator for corm size at harvest. Interestingly, peduncle length, unlike peduncle diameter, was not affected by corm size. Sugiyama and Santosa (2008) stated that the petiole length in Amorphophallus species was strongly affected by planting material, fertilizer application, light intensity, watering frequency and leaf number. Nevertheless, factors affecting peduncle length is still unclear in the present study. Corm size also affected the length of spadix, female and male zones (Table 3). Larger corms produced larger spadix, vice versa. On the other hand, the length of spathe, reproductive part (female+male zones), and appendix were independent of corm size.

In A. muelleri, female zones length could be important in determining the number of seeds as compared with other Amorphophallus species. Figure 5 shows that the number of berries increases with increasing length of female zone $(\mathrm{p}<0.000)$, thus, effort to improve length of female zone is important to increase the number of seeds.

Table 2. Development stage of inflorescence organs in each growth stage of A. muelleri grown under $65 \%$ shading paranet in Bogor, Indonesia

\begin{tabular}{|c|c|c|c|c|c|c|c|}
\hline \multirow{2}{*}{ Stage } & \multirow{2}{*}{$\begin{array}{l}\text { Plant Age } \\
\text { (DAP) }\end{array}$} & \multirow{2}{*}{$\begin{array}{c}\text { Seed } \\
\text { Maturity }\end{array}$} & \multicolumn{5}{|c|}{ Color Flower Organ } \\
\hline & & & Pde & Spe & Berry & MF & Apx \\
\hline $\mathrm{I}$ & 0 & immature & $-^{z}$ & - & - & - & - \\
\hline II & $56-71$ & immature & $\begin{array}{l}\text { LP- } \\
\text { PK }\end{array}$ & $\begin{array}{l}\text { CW to } \\
\text { GN }\end{array}$ & $\begin{array}{c}\text { CW-LG; Stigma } \\
\text { lobe LY }\end{array}$ & $\begin{array}{l}\text { CW to } \\
\text { LY }\end{array}$ & $\begin{array}{c}\text { CW to } \\
\text { LY }\end{array}$ \\
\hline III & $75-84$ & immature & LG & LG-PK & $\begin{array}{c}\text { PK } \\
\text { Stigma lobe LY }\end{array}$ & $\mathrm{Y}$ & $\mathrm{CW}$ \\
\hline IV & $80-88$ & immature & LG & $\begin{array}{l}\text { LG- } \\
\text { PK-PP }\end{array}$ & $\begin{array}{c}\text { PK } \\
\text { Stigma lobe LY }\end{array}$ & DY & W-PP \\
\hline V & $84-93$ & immature & DG & $\begin{array}{l}\text { LG- } \\
\text { PK-PP }\end{array}$ & $\begin{array}{c}\text { PK } \\
\text { Stigma lobe LY }\end{array}$ & DY & W-PP \\
\hline VI & $87-97$ & immature & DG & wither & LP & Wither & Wither \\
\hline VII & $368-405$ & mature & DG & - & $\begin{array}{c}\text { LP to BG to BY to } \\
\text { BR }\end{array}$ & - & - \\
\hline
\end{tabular}

DAP-day after planting; ${ }^{2}$ Not visible by naked eye; Pde-peduncle, Spe-spathe, FF-female flower, MFmale flower, Apx-Appendix; BG-bright green, BR-bright red, BY-bright yellow, CW-creamy white, DGdark green, DY-dark yellow, GN-greenish, LP-light pink, LG-light green, LY-light yellow, P-pink, PKpinkish, PP-purplish, and W-white. 
Table 3. Value of Pearson correlation among flower organs length of A. muelleri

\begin{tabular}{lcccccccc}
\hline & $\begin{array}{c}\text { Corm } \\
\varnothing(\mathrm{cm})\end{array}$ & $\begin{array}{c}\text { Pde } \\
(\mathrm{cm})\end{array}$ & $\begin{array}{c}\text { Pde } \varnothing \\
(\mathrm{cm})\end{array}$ & $\begin{array}{c}\text { Spx } \\
(\mathrm{cm})\end{array}$ & $\begin{array}{c}\text { FZ } \\
(\mathrm{cm})\end{array}$ & $\begin{array}{c}\text { MZ } \\
(\mathrm{cm})\end{array}$ & $\begin{array}{c}\text { Spe } \\
(\mathrm{cm})\end{array}$ & $\begin{array}{c}\text { Rep } \\
(\mathrm{cm})\end{array}$ \\
\hline Corm $\varnothing(\mathrm{cm})$ & & & & & & & & \\
Pde $(\mathrm{cm})$ & $0.146^{\mathrm{NS}}$ & & & & & & & \\
Pde $\varnothing(\mathrm{cm})$ & $0.687^{* *}$ & $0.490^{\mathrm{NS}}$ & & & & & & \\
Spx $(\mathrm{cm})$ & $0.612^{* *}$ & $0.729^{* *}$ & $0.831^{* *}$ & & & & & \\
$\mathrm{FZ}(\mathrm{cm})$ & $0.685^{* *}$ & $0.612^{*}$ & $0.774^{* *}$ & $0.890^{* *}$ & & & & \\
$\mathrm{MZ}(\mathrm{cm})$ & $0.685^{* *}$ & $0.612^{*}$ & $0.612^{* *}$ & $0.890^{* *}$ & $1.000^{* *}$ & & & \\
Spe $(\mathrm{cm})$ & $0.545^{\mathrm{NS}}$ & $0.643^{* *}$ & $0.826^{* *}$ & $0.915^{* *}$ & $0.797^{* *}$ & $0.797^{* *}$ & & \\
Rep $(\mathrm{cm})$ & $0.395^{\mathrm{NS}}$ & $0.937^{* *}$ & $0.701^{* *}$ & $0.922^{* *}$ & $0.800^{* *}$ & $0.800^{* *}$ & $0.830^{* *}$ & \\
Apx $(\mathrm{cm})$ & $0.560^{\mathrm{NS}}$ & $0.767^{* *}$ & $0.764^{* *}$ & $0.986^{* *}$ & $0.843^{* *}$ & $0.843^{* *}$ & $0.884^{* *}$ & $0.936^{* *}$ \\
\hline
\end{tabular}

Average diameter $(\varnothing)$ measured at the base, middle and upper parts; NS-non significant, ${ }^{* *}$ Significant at $\mathrm{P}<0.000, *$ Significant at $\mathrm{P} \leq 0.001$; Pde-peduncle; Spx-spadix, FZ-female zone, MZ-male zone, Spespathe, Apx-appendix, Rep-reproductive (female+male zones).

At anthesis, ovary $(1.6 \pm 0.2 \mathrm{~mm}$ in diameter) was commonly arranged spirally (Figure 4E and 4F) without any space between them, but sometimes it was sparsely arranged by about 0.5 to $1.1 \mathrm{~mm}$ in distance. Simply, number of berry production could be calculated by multiplying vertical and horizontal arrangement. However, estimating berry production should consider length of stipule (Figure 4F) and berry arrangement, to reduce over counting. Considering two seeds in each berry, seed number of a spadix in $A$. muelleri is by doubling number of berry.

As an apomict (Jansen et al., 1996), the pollination is not mandatory for seed set in $A$. muelleri. We have speculated that male flowers of A. muelleri is unlikely playing important role on seed production, but more prominent from ecological point of views like in other species (Kite and Hetterschieid, 1997; Heiduk et al., 2010; Gottsberger et al., 2012) because many Nitidulidae insects visited the spadix, mated and foraged pollen during anthesis.

Number of male flower significantly correlated with the length of male zone $(\mathrm{p}<0.000$, data not shown) where inflorescence with larger male zone had more male flower. Figure 6 shows that length of peduncle and appendix increased with increasing size of inflorescence. At anthesis, peduncle was longer than appendix, and both male and female zones were the shortest. In Arum maculatum (Araceae), Chartier and Gibernau (2009) reported that appendix was longer than female flower zone whereas female zone was longer than male flower zone. It is likely that spadix size of $A$. muelleri is dependent on peduncle and appendix sizes (Figure 6). On the other hand, female zone length correlates loosely with spadix size $(\mathrm{p}<0.0000)$.

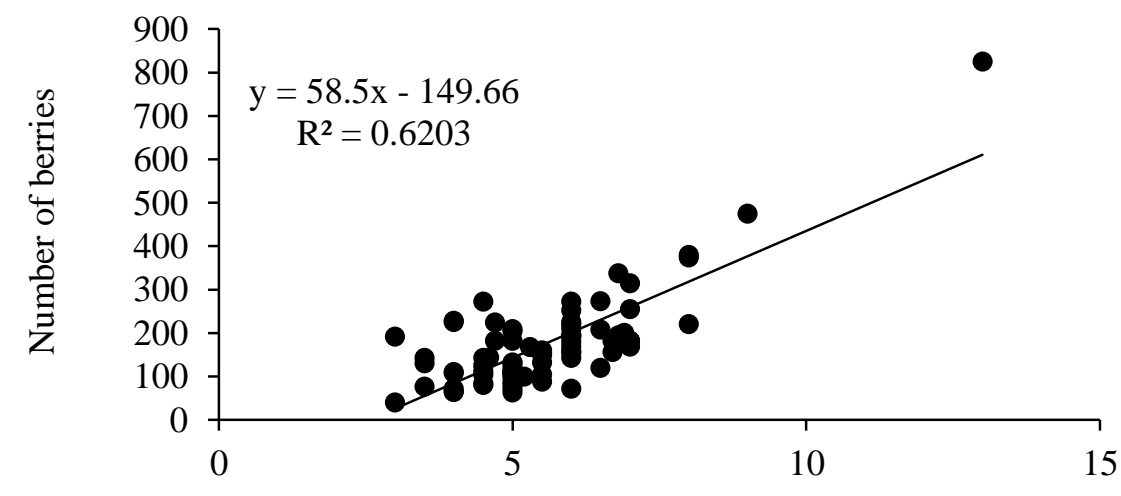

Female zone length $(\mathrm{cm})$

Figure 5. Correlation between number of berries and length of female zone in A. muelleri $(\mathrm{n}=78)$. 


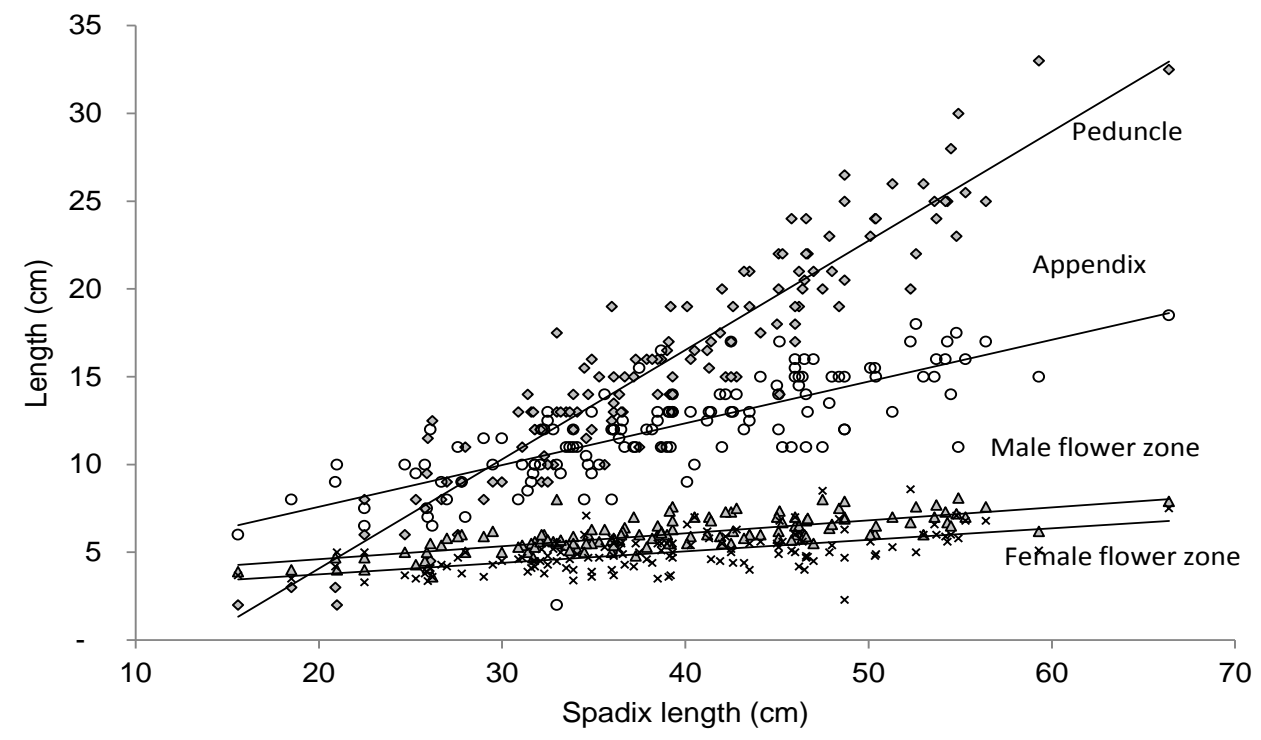

Figure 6. Relationship between the length of spadix and length of floral zones (peduncle $\left[R^{2}=0.883\right.$, $\mathrm{P}<0.000]$, appendix $\left[\mathrm{R}^{2}=0.605, \mathrm{P}<0.000\right]$, male flower $\left[\mathrm{R}^{2}=0.546, \mathrm{P}<0.000\right]$, and female flower $\left.\left[R^{2}=0.337, P<0.000\right]\right)$. Slope between male and female zones is not significant different). $\mathrm{R}^{2}$-coefficient correlation.

Present study indicates that flower morphology, i.e., spadix size, length of female zone, lobe number and rooting ability could affect seed production. Further studies are necessary in order to develop efficient methods of seed production, especially improving biomass allocation to reproductive organ of A. muelleri flower.

\section{CONCLUSION}

Growth of A. muelleri flower showed three distinct phases; slow, rapid and seed maturation phases. Corm diameter determined the peduncle diameter and the lengths of spadix, female and male zones, whereas length of peduncle, length of spathe, reproductive zone and appendix were independent of corm size. Length of female zone determined the numbers of berries. Present study implies the need to select flower with larger female zone and large corms for efficient seed production of A. muelleri.

\section{ACKNOWLEDGEMENTS}

This collaborative study between Bogor Agricultural University, Indonesia and Tokyo University of Agriculture, Japan was supported by the Strategic Applied Research (PSA-PUPT) No 083/SP2H/PL/Dit.Litabmas/ II/2015 (IPB No. 604/IT3.11/PL/2015) FY 2015 and No 079/SP2H/LT/DRPM/II/2016 (IPB No. 600/IT3.11/PN/2016) FY 2016 from Ministry of Research and Technology and Higher Education (Menristekdikti), Republic of Indonesia.

\section{REFERENCES}

Alonso-Sande, M., D. Teijeiro-Osorio, C. Remuñán-López, M.J. Alonso. 2009. Glucomannan, a promising polysaccharide for biopharmaceutical purposes. Eur. J. Pharmaceutics and Biopharmaceutics. 72: 453-462.

Chartier, M., M. Gibernau. 2009. Size variation of flowering in Arum maculatum (Araceae). Aroideana. 32: 153-158.

Ekawati, R., A.D. Susila, J.G. Kartika. 2010. The effect of shade on growth and productivity of several indigenous vegetable. J. Hort. Indonesia. 1(1): 4652. 
Gottsberger, G., I. Silberbauer-Gottsberger, R.S. Seymour, S. Dötterl. 2012. Pollination ecology of Magnolia ovata may explain the overall large flower size of the genus. Flora - Morphology, Distribution, Functional Ecology of Plants. 207(2): 107-118.

Hand, M. L., A.G. Koltunow. 2014. The genetic control of apomixis: asexual seed formation. Genetics. 197(2): 441-450.

Heiduk, A., I. Brake, T. Tolasch, J. Frank, A. Jürgens, U. Meve, S. Dötterl. 2010. Scent chemistry and pollinator attraction in the deceptive trap flowers of Ceropegiado lichophylla. South Afr. J. Botany. 76(4): 762-769.

Jansen, P.C.M., C.V.D. Wilk, W.L.A. Hetterscheid. 1996. Amorphophallus Blume ex. Decaisne. Pp. 45-50. In M. Flach, F. Rumawas (Eds). PROSEA: Plant Resources of South-East Asia. No.9. Plant Yielding Non-seed Carbohydrates. Backhuys Publisher. Leiden.

Kite, G.C. W.L.A. Hetterschieid. 1997. Inflorescence odors of Amorphophallus and Pseudodracontium (Araceae). Phytochemistry. 46(1): 71-75.

Ohtsuki, T. 1968. Studies on reserve carbohydrates of four Amorphophallus species, with special reference to mannan. Botanical Magazine Tokyo. 81: 119-126.

Santosa, E. 2014. Development of iles-iles in intercropping system to enhance farmer welfare and sovereignty on national food industries. Risalah Kebijakan Pertanian dan Lingkungan. 1(2): 73-79.
(Indonesian with English summary).

Santosa, E., N. Sugiyama, S. Hikosaka, S. Kawabata. 2003. Cultivation of Amorphophallus muelleri Blume in timber forests of east Java. Japanese J. Trop. Agriculture. 47(3): 190-197.

Sugiyama, N., E. Santosa. 2008. Edible Amorphophallus in Indonesia-Potential Crops in Agroforestry. Gajah Mada Press, Yogyakarta. Indonesia. 125p.

Sumarwoto. 2005. Iles-iles (Amorphophallus mиelleri Blume); description and other characteristics. Biodiversitas. 6(3): 185190.

Zhang, D., Q. Wang, S. George. 2010. Mechanism of staggered multiple seedling production from $A$. bulbifer and A. muelleri and its implication to cultivation in Southeast Asia. Trop. Agric. Dev. 54(3): 84-90.

Zhao, J., D. Zhang, G. Srzednicki, S Kanlayanarat, C. Borompichaichartkul. 2010. The morphological and growth characteristics of Amorphophallus muelleri Blume - a commercially important konjac species. Acta Horticulturae. 875: 501-508.

Zhao, J.R., L. Yu, G. Srzednicki, C. Borompichaichartkul. 2013. Effects of different concentrations of gibberellin on flower-bud differentiation of Amorphophallus muelleri. Pp 93-99. In Proceedings of Agriculture Food for Health and Wealth 2013. International Symposium on Agri-Foods for Health and Wealth, Golden Tulip Sovereign Hotel, August 5-8, 2013, Bangkok, Thailand. 